\title{
The Current Landscape of Long-acting Growth Hormone Therapy
}

\section{Srushti Sodha*}

University of the Sciences, Philadelphia, PA, USA 19104

*Corresponding Author: Srushti Sodha, University of the Sciences, Philadelphia, PA, USA 19104.
Received: August 05, 2021

Published: September 06, 2021

(C) All rights are reserved by Srushti Sodha.

\begin{abstract}
Growth hormone deficiency is a rare disease characterized by short stature, delay in maturation and growth of children due to poor development of the skeletal tissue. The current market for GHD treatment consists of once daily injections as a replacement therapy to growth hormone. The review commences by summarizing the existing FDA approved formulations, with their indications, challenges and dosage regimen. Furthermore, we have reviewed the progress and challenges associated with the long acting formulations undergoing clinical trials currently. Various research projects have implemented alternative routes of delivery such as pulmonary and transdermal, or used nano-systems for controlled release of hGH, thereby reducing the dosing frequency. Our aim is to shed some light on these approaches, while also evaluating their feasibility of traversing from bench to bedside. In this rapidly transient field, we aim to emphasize this review on the research published during or after 2015.
\end{abstract}

Keywords: Long-acting hGH; PEGylation; Fusion Proteins; Lipidation

\section{Abbreviations}

hGH: Human Growth Hormone; GHD: Growth Hormone Deficiency; FDA: Food and Drug Administration; HAS: Human Serum Albumin; IGF-1: Insulin Like Growth Factor 1; IGFBP: IGF Binding Protein; PEG: poly (ethylene glycol); CTP: C-Terminal Peptide; hCG: human Chorionic Gonadotropin; mPEG: methoxy-poly (ethylene glycol); PK/PD: Pharmacokinetics Pharmacodynamics; GFP: Green Fluorescent Protein; SLN: Solid Lipid Nanoparticles; TMC: Trimethyl Chitosan; TDM: Tetradecyl- $\beta$-D-maltoside; P.L.E.A.S.E.: Precise Laser Epidermal System; SR-hGH: Sustained Release Hgh; PVP: Polyvinyl Pyruvate; PAA-cys: Poly Acrylic Acid Cysteine; hcBD: Human Chitin Binding Domain; PLGA: Poly (Lactide-co-glycolide).

\section{Introduction}

National organization of rare diseases considers growth hormone deficiency (GHD) as a rare disease characterized by insufficient secretion of Growth Hormone (GH) from anterior pituitary gland. GHD can be innate (congenital GHD), acquired GHD, or may result from an unknown cause (idiopathic GHD). When observed in children, it results in delayed maturation and growth of the child due to poor growth and development of the skeletal tissue. About 1:4000 children are growth hormone deficient [1]. In adults, GHD is less prevalent and maybe a result of direct trauma to the anterior brain (pituitary gland).

The human growth hormone is a 191 amino acid containing protein with molecular weight of about $22 \mathrm{kDa}$ and isoelectric $\mathrm{pH}$ of 5.8. This pituitary endocrine hormone has been extensively studied for decades, and the active residues identified by alanine scanning mutagenesis are F10, N12, I58, R64, Q68, K167, D171, K172, E174, F176, C182 and V185 [2]. The hormone regulates postnatal growth and metabolism. Normal hGH blood levels vary with age, gender, physiological condition, environmental factors and so on. It is clinically used with prescription for replacement therapy in patients with growth hormone deficiency. Being a protein, the delivery of hGH is challenging. It has a very short plasma half-life of about 3.4 hours after subcutaneous administration and 0.36 hours after intraveneous injection [3]. The following paper aims to dis- 
cuss and summarize the advancements in hGH therapy research, the existing formulations and the challenges to be addressed.

FDA approved formulations: The current picture of hGH therapeutics

Currently, the hGH market is limited to six FDA approved hGH formulations, all of which are daily subcutaneous injections. $\mathrm{Nu}$ - tropin depot was the only long-acting FDA approved hGH formulation but was withdrawn in 2004 due to commercialization and manufacturing difficulties. The dosage regimen, indications, side effects and formulation components of these formulations, along with those of Nutropin depot are comprehensively listed in table 1 and 2.

\begin{tabular}{|c|c|c|c|}
\hline Treatment & $\begin{array}{c}\text { Active } \\
\text { ingredient }\end{array}$ & Delivery system & Duration of action \\
\hline $\begin{array}{l}\text { Humatrope (Injection } \\
\text { vials and cartridges) - } \\
\text { Lilly [65] }\end{array}$ & $\begin{array}{l}191 \text { amino acid pro- } \\
\text { tein, MW 22,124 Da, } \\
\text { structure similar to } \\
\text { hGH, synthesized in } E \text {. } \\
\text { coli strain. }\end{array}$ & $\begin{array}{c}\text { For injection vials: } \\
5 \text { mg somatropin, } 25 \text { mg mannitol, } 5 \text { mg glycine, } 1.13 \text { mg diba- } \\
\text { sic sodium phosphate supplied with a diluent }(5 \mathrm{~mL}) \text { with } 0.3 \% \\
\text { metacresol and } 1.7 \% \text { glycerine. } \\
\text { For cartridge: } \\
\text { 6/12/24 mg somatropin, } 18 / 36 / 72 \text { mg mannitol, } 6 / 12 / 24 \\
\text { mg glycine, } 1.36 / 2.72 / 5.43 \text { dibasic sodium phosphate with } \\
3 \mathrm{~mL} \text { diluent (water for injection with } 0.3 \% \text { metacresol and } \\
1.7 \% / 0.29 \% / 0.29 \% \text { glycerol respectively). }\end{array}$ & 12 - 18 hours \\
\hline $\begin{array}{l}\text { Genotropin (Pfizer) } \\
\text { [66] }\end{array}$ & $\begin{array}{l}\text { Lyophilized pow- } \\
\text { der,191 amino acid } \\
\text { protein, MW 22,124 } \\
\text { Da, structure similar to } \\
\text { hGH, synthesized in } E \text {. } \\
\quad \text { coli strain. }\end{array}$ & $\begin{array}{c}\text { Front chamber: } \\
\text { Somatropin 5.8mg, glycine } 2.2 \mathrm{mg} \text {, mannitol } 1.8 \mathrm{mg} \text {, sodium di- } \\
\text { hydrogen phosphate anhydrous } 0.32 \mathrm{mg} \text {, disodium phosphate } \\
\text { anhydrous } 0.31 \mathrm{mg} \text {. } \\
\text { Rear chamber: } \\
1.14 \mathrm{~mL} \text { water for injection with } 0.3 \% \mathrm{~m} \text {-cresol, } 45 \mathrm{mg} \text { man- } \\
\text { nitol. }\end{array}$ & $\begin{array}{l}\text { Less than } 24 \text { hours } \\
\left(t_{1 / 2} \text { of about } 3 \text { hrs. }\right)\end{array}$ \\
\hline $\begin{array}{l}\text { Saizen - EMD Serono } \\
\text { [67] }\end{array}$ & $\begin{array}{l}191 \text { amino acid pro- } \\
\text { tein, MW 22,125 Da, } \\
\text { structure similar to } \\
\text { hGH, synthesized in } E \text {. } \\
\text { coli strain. }\end{array}$ & $\begin{array}{c}\text { Subcutaneous or Intramuscular injection available in vials. } \\
\text { Vial (5mg and } 8.8 \mathrm{mg} \text { strengths): } \\
\text { Somatropin 5mg, sucrose } 34.2 \mathrm{mg}, 1.16 \text { O-phosphoric acid. pH } \\
\text { adjusted with 0-phosphoric acid or } \mathrm{NaOH} \text {. } \\
\text { Diluent is USP sterile water for injection with } 0.9 \% \text { with benzyl } \\
\text { alcohol as antimicrobial preservative. }\end{array}$ & $\begin{array}{l}\mathrm{t}_{1 / 2} \text { of about } 1.27 \mathrm{hr} \\
\text { for } \mathrm{SC} \text { and } 3 \mathrm{hr} \text {. for } \\
\text { IM route, overall less } \\
\text { than } 24 \text { hours. }\end{array}$ \\
\hline
\end{tabular}




\begin{tabular}{|c|c|c|c|}
\hline Tev-Tropin - Teva [69] & $\begin{array}{l}191 \text { amino acid pro- } \\
\text { tein, MW 22,124 Da, } \\
\text { structure similar to } \\
\text { hGH, synthesized in } E \text {. } \\
\text { coli strain. }\end{array}$ & $\begin{array}{l}\text { Subcutaneous injection: } \\
\text { Lyophilized somatropin } 5 \mathrm{mg} \text {, mannitol } 30 \mathrm{mg} \text {. } \\
\text { Diluent sterile } 0.9 \% \text { water for injection preserved with Benzyl } \\
\text { Alcohol }\end{array}$ & $\begin{array}{l}\mathrm{t}_{1 / 2} \text { of about } 1.27 \mathrm{hr} \text {. } \\
\text { for SC and } 25 \text { minutes } \\
\text { for IV route, overall } \\
\text { less than } 24 \text { hours. }\end{array}$ \\
\hline $\begin{array}{l}\text { Omnitrope - Sandoz } \\
\text { [70] }\end{array}$ & $\begin{array}{l}191 \text { amino acid pro- } \\
\text { tein, MW 22,124 Da, } \\
\text { structure similar to } \\
\text { hGH, synthesized in } E \text {. } \\
\text { coli strain. }\end{array}$ & $\begin{array}{c}\text { Cartridge: } \\
\text { 5mg Somatropin, } 13.5 \mathrm{mg} \text { benzyl alcohol, water for injection to } \\
\text { make total volume } 1.5 \mathrm{~mL} \text {. } \\
\text { Injection: } \\
\text { Somatropin } 1.5 \mathrm{mg} / 5.8 \mathrm{mg} \text {, glycine } 27.6 \mathrm{mg} \text {, benzyl alco- } \\
\text { hol 0mg/17 mg, sterile water for injection to make volume } \\
1.13 \mathrm{~mL} / 1.14 \mathrm{~mL} \text {. }\end{array}$ & $\begin{array}{l}\mathrm{t}_{1 / 2} \text { of about } 1.27 \mathrm{hr} \\
\text { for } \mathrm{SC} \text { and } 3 \mathrm{hr} \text {. for } \\
\text { IM route, overall less } \\
\quad \text { than } 24 \text { hours. }\end{array}$ \\
\hline
\end{tabular}

Table 1: FDA approved formulations, the delivery systems and durations of action.

\begin{tabular}{|c|c|c|c|}
\hline Treatment & Indication (s) & Dosage & Known side effects \\
\hline $\begin{array}{l}\text { Somatropin (Nu- } \\
\text { tropin) - Genen- } \\
\text { tech [55] } \\
\text { (Discontinued in } \\
\text { 2004) }\end{array}$ & $\begin{array}{l}\text { For children and teenag- } \\
\text { ers with short stature or } \\
\text { inadequate growth patterns; } \\
\text { Turner syndrome*; chronic } \\
\text { kidney disease (CKD) up to } \\
\text { the time of kidney transplant. }\end{array}$ & $13.5 \mathrm{mg} / 18 \mathrm{mg} / 22.5 \mathrm{mg}$ & $\begin{array}{l}\text { Swelling, joint pain, carpal tunnel } \\
\text { syndrome, injection site effects like } \\
\text { pain, swelling, irritation. }\end{array}$ \\
\hline $\begin{array}{l}\text { Humatrope (In- } \\
\text { jection vials and } \\
\text { cartridges) - Lilly } \\
\text { [65] }\end{array}$ & $\begin{array}{l}\text { For long-term treatment } \\
\text { of GHD children and adults } \\
\text { (adult or childhood onset), } \\
\text { and children with idiopathic } \\
\text { short stature (non-growth } \\
\text { hormone deficient short } \\
\text { stature) }\end{array}$ & $\begin{array}{l}\text { Pediatric patients: } \\
\text { GHD: } 0.18 \mathrm{mg} / \mathrm{kg} \text { to } 0.30 \mathrm{mg} / \mathrm{kg} \text { - } 3 \text { weekly } \\
\text { doses given daily or on } 3 \text { alternate days } 6 \\
\text { times a week; } \\
\text { Turner syndrome: } 0.375 \mathrm{mg} / \mathrm{kg} \text { per week. } \\
\text { Idiopathic short stature: weekly dose of } \\
0.37 \mathrm{mg} / \mathrm{kg} \text { divided evenly and adminis- } \\
\text { tered } 6-7 \text { times per week. }\end{array}$ & $\begin{array}{l}\text { Development of anti-hGH antibodies; } \\
\text { Turner syndrome patients reported } \\
\text { otitis media, ear disorders; in adult } \\
\text { patient clinical trials, headache, mild } \\
\text { hyperglycemia, glucosuria, pain and } \\
\text { weakness were reported; although } \\
\text { in doubt, no certain correlation has } \\
\text { been established between treatment } \\
\text { with Humatrope and occurrence of } \\
\text { diabetes or leukemia. }\end{array}$ \\
\hline $\begin{array}{l}\text { Genotropin } \\
\text { (Pfizer) [66] }\end{array}$ & $\begin{array}{l}\text { Children suffering from } \\
\text { idiopathic short stature, GHD, } \\
\text { small for gestational age, } \\
\text { Prader Willi syndrome**, } \\
\text { Turner syndrome. } \\
\text { Adults with childhood or } \\
\text { adult onset GHD. }\end{array}$ & $\begin{array}{l}\text { Pediatric: } \\
\text { idiopathic short stature } 0.47 \mathrm{mg} / \mathrm{kg} / \\
\text { week, GHD } 0.16-0.24 \mathrm{mg} / \mathrm{kg} / \mathrm{week} \text {, small } \\
\text { for gestational age } 0.48 \mathrm{mg} / \mathrm{kg} / \mathrm{week} \text {, } \\
\text { Prader Willi syndrome } 0.24 \mathrm{mg} / \mathrm{kg} / \text { week } \\
\text { **, Turner syndrome } 0.33 \mathrm{mg} / \mathrm{kg} / \text { week. } \\
\text { Adult: } \\
\text { \#Weight based from } 0.04 \mathrm{mg} / \mathrm{kg} / \mathrm{week} \text { in- } \\
\text { creasing up to maximum of } 0.08 \mathrm{mg} / \mathrm{kg} / \\
\text { week at } 4-8 \text { weeks. } \\
\text { \#Non-weight based: starting at } 0.2 \mathrm{mg} / \\
\text { day, increasing gradually at } 1-2-\mathrm{month} \\
\text { intervals by } 0.1-0.2 \mathrm{mg} / \mathrm{day} \text {. }\end{array}$ & $\begin{array}{l}\text { Injection site reactions, lipoatrophy, } \\
\text { headaches, } \\
\text { Reports of sudden deaths in obese } \\
\text { children with Prader Willi syndrome }\end{array}$ \\
\hline $\begin{array}{l}\text { Saizen - EMD } \\
\text { Serono [67] }\end{array}$ & $\begin{array}{l}\text { For long term treatment in } \\
\text { children with GHD, in adults } \\
\text { with childhood or adult onset } \\
\text { GHD. }\end{array}$ & $\begin{array}{c}\text { For adults starting at } 0.05 \mathrm{mg} / \mathrm{kg} / \text { day } \\
\text { which was for a month, if tolerated } \\
\text { increased by } 0.01 \mathrm{mg} / \mathrm{kg} / \text { day (weight } \\
\text { based); starting at } 0.2 \mathrm{mg} / \text { day, increasing } \\
\text { gradually at } 1-2-\text { month intervals by } 0.1 \text { - } \\
0.2 \mathrm{mg} / \text { day (non-weight based). } \\
\text { For children } 0.18 \mathrm{mg} / \mathrm{kg} \text { to } 0.30 \mathrm{mg} / \mathrm{kg} \text { - } 3 \\
\text { weekly doses given daily or on } 3 \text { alternate } \\
\text { days } 6 \text { times a week. }\end{array}$ & $\begin{array}{c}\text { Arthralgia, headache, skeletal pain, } \\
\text { dizziness, influenza-like symptoms, } \\
\text { back pain, edema peripheral, myal- } \\
\text { gia, rhinitis, upper respiratory tract } \\
\text { infection, paraesthesia, hypoaesthe- } \\
\text { sia, carpal tunnel syndrome, chest } \\
\text { pain, depression, hypothyroidism, } \\
\text { insomnia. }\end{array}$ \\
\hline
\end{tabular}




\begin{tabular}{|c|c|c|c|}
\hline $\begin{array}{l}\text { Norditropin - } \\
\text { Novo Nordisk } \\
{[68]}\end{array}$ & $\begin{array}{l}\text { Pediatric: GHD, Noonan syn- } \\
\text { drome****, small at gestation- } \\
\text { al age, Turner Syndrome. } \\
\text { Adults: GHD adult or child- } \\
\text { hood onset. }\end{array}$ & $\begin{array}{c}\text { Pediatric: } \\
\text { GHD } 0.34 \mathrm{mg} / \mathrm{kg} / \text { day for } 6-7 \text { times a } \\
\text { week, Noonan syndrome } 0.66 \mathrm{mg} / \mathrm{kg} / \text { day, } \\
\text { small at gestational age } 0.67 \mathrm{mg} / \mathrm{kg} / \text { day, } \\
\text { Turner Syndrome } 0.67 \mathrm{mg} / \mathrm{kg} / \text { day. } \\
\text { Adults: } \\
\text { Starting at } 0.004 \mathrm{mg} / \mathrm{kg} / \text { day for six } \\
\text { weeks, if tolerated increased by } 0.016 \\
\mathrm{mg} / \mathrm{kg} / \text { day (weight based); starting } \\
\text { at } 0.2 \mathrm{mg} / \text { day, increasing gradually at } \\
1-2-\mathrm{month} \text { intervals by } 0.1-0.2 \mathrm{mg} / \text { day } \\
\text { (non-weight based). }\end{array}$ & $\begin{array}{c}\text { Injection site reactions, lipoatrophy, } \\
\text { headaches. }\end{array}$ \\
\hline $\begin{array}{l}\text { Tev-Tropin - Teva } \\
\text { [69] }\end{array}$ & $\begin{array}{l}\text { Pediatric: } \\
\text { Growth failure due to inad- } \\
\text { equate secretion of growth } \\
\text { hormone. }\end{array}$ & $\begin{array}{l}\text { Up to } 0.1 \mathrm{mg} / \mathrm{kg} 3 \text { times per week SC } \\
\text { injection is recommended. }\end{array}$ & Headache, injection site reactions. \\
\hline $\begin{array}{l}\text { Omnitrope - San- } \\
\text { doz [70] }\end{array}$ & $\begin{array}{l}\text { Children with GHD short } \\
\text { stature, } \\
\text { Adults with childhood or } \\
\text { adult onset GHD. }\end{array}$ & $\begin{array}{c}\text { Pediatric: } \\
0.16-0.24 \mathrm{mg} / \mathrm{kg} / \text { week divided into 6-7 } \\
\text { equal dose injections. } \\
\text { Adults: } \\
0.04 \mathrm{mg} / \mathrm{kg} / \text { week, if tolerated for a } \\
\text { month increased to } 0.08 \mathrm{mg} / \mathrm{kg} / \text { week. }\end{array}$ & $\begin{array}{l}\text { Headache, injection site reactions, } \\
\text { lipoatrophy. }\end{array}$ \\
\hline
\end{tabular}

Table 2: FDA approved formulations, Indications, dosage and known side effects.

\section{Emerging therapies}

Albumin binding hGH

Albumin is a long-circulating blood protein with multiple ligand binding sites, that can be harnessed to prolong the circulation halflife of rapidly clearing therapeutic agents [4]. A variety of protein modifications are used to introduce albumin binding ability, such as introduction of ankyrin domain [5], site-specific fatty acid conjugation [6] or fusing the protein of interest with the Albumin Binding Domain (ABD) from another protein [7].

NC-0195-0092, also known as Somapacitan, is an albumin binding, long-acting variant of Somatropin. A single point mutation in introduced to the hGH backbone in order to attach a fatty acid chain with albumin binding characteristics. Albumin binding increases the circulation time of molecules by sterically shielding proteolytic degradation and preventing rapid glomerular filtration due to large size of human serum albumin (HSA) [8]. The chemical structure of Somapacitan is shown in figure 1. Pre-clinical studies in hypophysectomized rats, mini-pigs and cynomolgus monkeys demonstrated absence of in vivo toxicity and mutagenicity [9]. A double-blinded, randomized, placebo-controlled study for single (once-weekly) and multiple dose tolerance on non-Asian and Japanese healthy male volunteers showed that once weekly doses of $0.02-0.24 \mathrm{mg} / \mathrm{kg}$ and multiple doses of $0.01-0.32 \mathrm{mg} / \mathrm{kg}$ were tolerated by all volunteers [10]. To further evaluate the safety and tolerability of this treatment in GHD patients, 34 GHD patients were recruited and randomized, after a 14-day cleansing period during which no hGH was given. The control group was administered once daily Norditropin, and the treatment groups were given once weekly NC-0195-0092, at doses 0.02, 0.04, 0.08 and $0.12 \mathrm{mg} / \mathrm{kg}$. the number of adverse events were similar to norditropin for doses $0.02,0.04,0.08 \mathrm{mg} / \mathrm{kg}$, but were higher for $0.12 \mathrm{mg} / \mathrm{kg}$ dose. However, the overall treatment was found to be safe and no anti-hGH antibodies or adverse effects besides those observed in conventional hGH therapy were observed [11]. The group concluded that the treatment may prove to be efficacious in humans and may serve as a once-weekly breakthrough treatment [12]. In pre-pubertal children (6-13 y.o.), once weekly administration of NC-0195-0092 was 
well tolerated up to $0.16 \mathrm{mg} / \mathrm{kg}$, demonstrating that this may be a good long-acting GH therapy for children [13]. In September 2018, a clinical trial to demonstrate the efficacy of Somapacitan was published. The results indicated that once weekly administration of Somapacitan at $0.08 \mathrm{mg} / \mathrm{kg}$ and $0.16 \mathrm{MH} / \mathrm{kg}$ showed comparable annualized height growth velocity results to daily Norditropin administered at $0.034 \mathrm{mg} / \mathrm{kg} /$ day in GHD children [14].

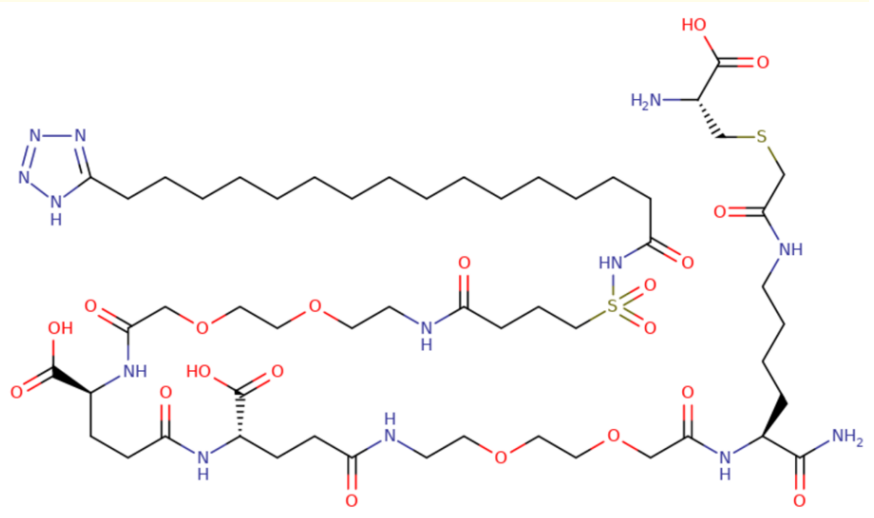

Figure 1: Chemical structure of Somapacitan with the fatty acid chain [15].

\section{HSA - hGH fusion protein}

Development of albumin fused proteins has been utilized for increasing the circulation half-life of low molecular weight, rapidly cleared proteins [16], aiding extracellular secretion of protein of interest by utilizing co-overexpression of secretion factors [17] or slow release of protein in the blood stream by utilizing protease activity, thereby making the fusion protein approach a sustained release technology [18].

TV-1106, prepared by Teva Pharmaceuticals Ltd., is a fusion protein of human growth hormone and human serum albumin. Also known as albusomatropin, this protein is prepared by fusing a gene of human growth hormone to human serum albumin, has the ability to stimulate the levels if IGF-1, thereby confirming its activity as a somatropin receptor agonist It has an inherently long terminal elimination half-life of 23-35 hours, and remains in systemic circulation for about 7 days [19]. Pre-clinical studies in Cynomolgus monkeys injected with $0,2,10$, and $20 \mathrm{mg} / \mathrm{kg}$ of TV-1106 showed no adverse effects or histopathological changes and elevated IGF1 levels, indicative of safety and efficacy [20]. The IGF-1 levels in- creased in a dose dependent manner and no severe adverse effects were reported in this study [19]. Healthy Japanese and Caucasian volunteers were subjected to subcutaneous TV-1106 at doses 7.5, 15,50 and $100 \mathrm{mg}$. It was observed that TV-1106 was slowly absorbed, with $t_{\max }$ of 10-30 hours and the mean half-life was 26-36 hours, with no severe adverse reactions being reported. IGF-1 and IGFBP3 were found to increase proportionately in dose dependent manner [21]. Children and adults with GHD were subjected to TV1106 and divided in four dose quartiles $-3.36-<8.96 \mathrm{mg}$, $\geqq 8.96$ $<12.32 \mathrm{mg}$, $\geqq 12.32-<15.12 \mathrm{mg}$ and $\geqq 15.12-\leq 31.92 \mathrm{mg}$ - with daily Genotropin injections as a control treatment. Although effective in a dose dependent manner, the treatment with TV-1106 showed extremely high variability [22].

\section{PEGylated hGH}

Attachment of polyethylene glycol (PEG) - a hydrophilic, nontoxic molecule with low immunogenicity - to a macromolecule is often harnessed to increase the hydrophilicity and molecular weight of the molecule. This increased molecular weight improves the serum half-life of hGH, and PEGylation of proteins has been shown safe [23].

Jintrolong, the PEGylated form of rhGH (peg-rhGH), is designed for once weekly administration. 40kDa branched, hydrophilic PEG is attached to the amino group on rhGH [24]. Nb-2 cell lines from NCBI demonstrated the activity of PEGylated hGH. Rats treated with PEGylated hGH and regular rhGH showed much longer half-life of PEGylated hGH and slightly more weight gain relative to unmodified rhGH, thus showing the superiority of PEGylated rhGH [25]. Administration of Jintrolong injections at doses 0.01, 0.06, 0.2, 0.5 or $0.8 \mathrm{mg} / \mathrm{kg}$ to healthy adult volunteers revealed that Jintrolong was safe with similar side effects as that of the control group that received once daily rhGH. It had a peak concentration time between 12 to 48 hours and half-life of 168 hours, both significantly higher than conventional rhGH [24]. A 25-week randomized study on GHD children subjected to $0.1 \mathrm{mg} / \mathrm{kg} /$ week Jintrolong, $0.2 \mathrm{mg} /$ $\mathrm{kg} /$ week Jintrolong once weekly injections and $0.25 \mathrm{mg} / \mathrm{kg} /$ week rhGH daily injections showed that the height velocity significantly improved in the Jintrolong group relative to the daily hGH, and a significant improvement in standard deviation of height velocity was also seen $(p<0.05)$. The study thereby demonstrated noninferiority of Jintrolong once weekly injection over daily administered rhGH [26]. Another small scale trial on children had similar results, thereby proving that Jintrolong has a prolonged half-life, higher maximum plasma concentration and slower elimination as 
compared to daily rhGH injections, as well as shows no progressive plasma accumulation [23].

\section{CTP modified hGH}

MOD-4023 is a long-acting, modified form of hGH, which contains the carboxy terminal peptide (CTP) of human chondrionic gonadotropin [27]. The CTP is derived from the terminal 28 residues of the human chorionic gonadrtropin (hCG) C-terminal [27]. The said 28 residue C-terminal peptide (CTP) is responsible for providing longevity to hCG when sustaining pregnancy. MOD-4023 is formed by attaching three CTPs to hGH (CTP-hGH-CTP-CTP) [27]. This fusion increases the serum half-life of hGH.

This peptide has a relatively lower binding affinity in vitro to human growth hormone receptor as compared to unmodified growth hormone, but significantly prolonged circulation time. Studies in Sprague-Dawley rats and Rhesus monkeys demonstrated that once in five days injection of MOD-4023 produced similar effects as daily rhGH [27]. In healthy Japanese and Caucasian adults, a placebo controlled study was performed at 2.5, 7.5 and $15 \mathrm{mg}$ weekly doses of MOD-3024, and demonstrated that the drug was safe and well tolerated at administered doses [28]. Clinical studies for MOD-4023 in GHD children demonstrated 5-10-fold increase in the plasma half-life as compared to the daily rhGH. $0.66 \mathrm{mg} / \mathrm{kg} / \mathrm{wk}$ dose of once weekly injection of MOD-3024 produced effects closest to $0.24 \mathrm{mg} / \mathrm{kg} / \mathrm{wk}$ dose of daily rhGH [29]. For optimizing dose for adults, MOD-3024 was administered in weekly doses of $18.5 \%$, $37 \%, 55.5 \%$ and $123.4 \%$ of individual hGH doses. All the doses were well tolerated, and except $18.5 \%$ dose, all were efficacious in maintaining the IGF-1 concentration. The PK and PD parameters were found to be dose dependent [30].

\section{Pro-drug approach}

Permanent PEGylation of hGH has been exploited for enhanced half-life due to slower renal filtration. Although about a dozen different PEGylated variants have been designed, most clinical trials have been discontinued due to adverse effects such as altered pharmacology, injection site lipoatrophy, vacuolation and dissatisfactory efficacy [31].

TransCon hGH is another long-acting variant, which employs the pro-drug approach. The rhGH is transiently linked to methoxypolyethylene glycol (m-PEG) carrier via a proprietary linker, as shown in figure 2. The methoxypolyethylene glycol acts as an inert, sustained-release carrier that releases active hGH slowly into the blood stream over a period of seven days [32]. In healthy male volunteers, TransCon was administered at doses ranging between $0.02 \mathrm{mg} / \mathrm{kg} /$ week and $0.24 \mathrm{mg} / \mathrm{kg} /$ week. It was shown in this active controlled (with Omnitrope) and placebo controlled clinical trial that all the doses were well tolerated. The IGF-1 and hGH levels increased in a dose dependent fashion [33]. In GHD adults, once weekly injection of TransCon at doses $0.02,0.04$ and 0.08 $\mathrm{mg} / \mathrm{kg} /$ week were compared to once daily injection of Omnitrope at a dose of $0.04 \mathrm{mg} / \mathrm{kg} /$ week. TransCon was well tolerated and demonstrated a dose dependent increase in growth hormone concentration, with headache and fatigue being the most common side-effects [34]. Active-controlled, multi-center, open label studies using $0.14,0.21$ and $0.30 \mathrm{mg} / \mathrm{kg} /$ week of once weekly TransCon versus Genotropin daily injections of $0.03 \mathrm{mg} / \mathrm{kg} /$ day showed that statistically similar mean height growth velocities were seen in pre-pubertal children suffering from GHD, and similar PK/PD parameters were observed [32].

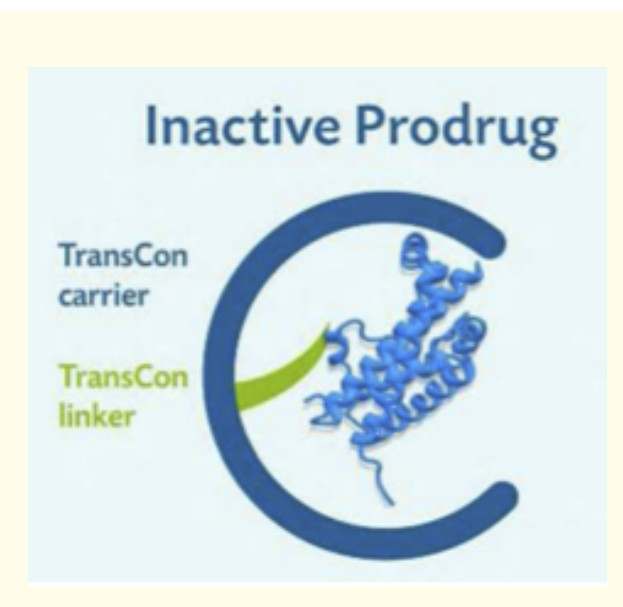

Figure 2: Diagrammatic structure of the pro-drug TransCon showing the carrier (dark blue), linker (green) and hGH molecule (light blue). This is the inactive form, which after cleavage gets rid of the inert carrier and releases hGH in a controlled fashion [32].

\section{XTEN - hGH fusion protein}

XTEN is an unstructured, recombinant polypeptide of 864 amino acids, with absence of hydrophobic residues, which cause immunogenicity and complicate manufacturing. This makes it a 
desirable candidate for fusion with proteins such as glucagon, hGH, exenatide and GFP which have very short biological half-lives [35]. Genetic fusion of XTEN amino acid sequence to native hGH N-terminus and C-terminus is known to reduce receptor mediated clearance, thereby increasing the half-life and thereby the potency [36].

Somavataran (VRS-317) is a fusion protein of the active domain rhGH and inactive domain of long chains of natural hydrophilic amino acids (XTEN). Although it is significantly less potent as compared to the native rhGH, extremely slow elimination rate allows longer tissue interaction and hence makes this molecule efficacious [37]. Naïve-to-treatment children underwent a clinical trial for dose optimization of Somavataran followed by dosing frequency optimization. Somavataran was administered at escalating doses $(0.8,1.2,1.8,2.7,4.0$, or $6.0 \mathrm{mg} / \mathrm{kg})$, leading to an observation that pharmacokinetics is dose dependent and higher doses lead to higher response, marked by IGF-1 levels. Furthermore, 1.15 $\mathrm{mg} / \mathrm{kg} /$ week, $2.5 \mathrm{mg} / \mathrm{kg}$ twice a month and $5.0 \mathrm{mg} / \mathrm{kg} / \mathrm{month}$ somavataran was administered. Mean height velocities were similar between groups, and the adverse reactions were mild and transient. The study showed tolerability and efficacy of Somavaran and frequencies of dosing it weekly, twice a month or monthly led to no significant differences [37]. Long term study indicated that mean height velocity remained consistent during all three years, height SDS continued to increase and treatment related adverse effects were transient and mild [38].

\section{Alternative delivery strategies}

\section{Pulmonary administration of hGH}

The pulmonary route of drug delivery has seen limelight in the past two decades, given its superiorities such as being a non-invasive and painless route, ability to bypass first pass metabolism of therapeutics, enabling longer retention of therapeutics and therefore absorption of larger amount of drug and ability to design metered dosage forms [39]. Various nanocarriers such as solid lipid nanoparticles (SLNs), inhalable microparticles for peptide and protein delivery are in various stages of preclinical development $[40,41]$. Dry powder for inhalation (DPI) formulations of insulin comprising of micronized drug with lactose as carrier have been explored and patented [42]. In order to enhance the bioavailability of hGH via pulmonary route to a commercially acceptable range, Solutol HS15 based system called the CriticalSorb was developed.
In rat models, it was observed that the extent of bioavailability was dependent on the concentration of Solutol HS15. It was seen that $10 \% \mathrm{w} / \mathrm{v}$ Solutol HS15 based diluent resulted in maximum absorption of hGH via nasal route, when compared to SC injection, as shown in figure 3 [43].

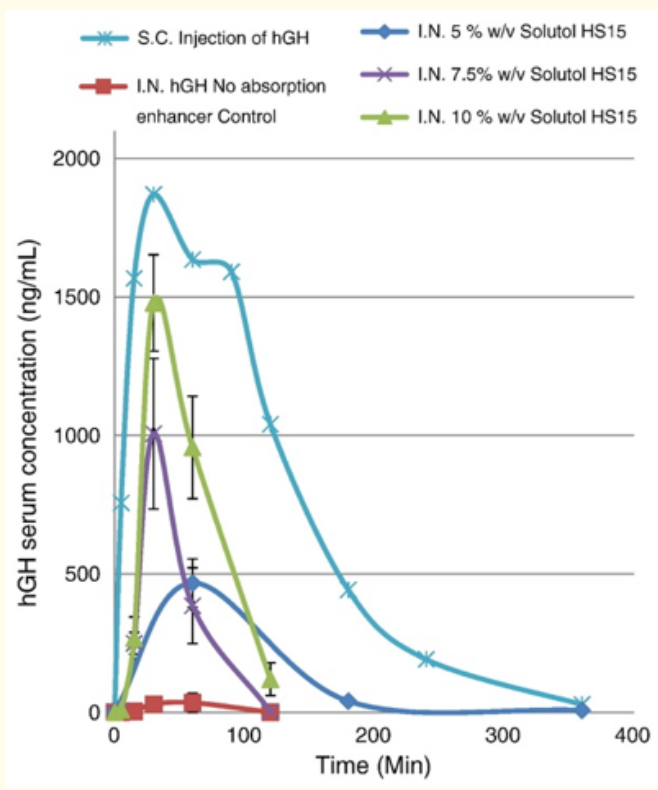

Figure 3: Graph of hGH serum concentration versus time for hGH delivered via pulmonary route by formulations containing varying amounts of Solutol HS15 compared to subcutaneous hGH injection [43].

The Pheroid technology is a relatively new fatty acid based drug delivery system [44]. Steyn and group evaluated Pheroid vesicles and Pheroid micro sponges for pulmonary drug delivery of rhGH and compared these methods to conventional SC injections in male Sprague Dawley rats, and showed a relative bioavailability increase of $38.9 \%$ and $128.5 \%$ respectively for Pheroid vesicles and Pheroid micro sponges. The same group evaluated well established absorption enhancers N-trimethyl chitosan chlorides (TMC H-L and TMC $\mathrm{H}-\mathrm{H}$ ) and showed a significant increase in absorption [45]. It was shown that Pheroids increased bioavailability by providing a longer residence time to $\mathrm{rhGH}$, while quartenization of TMC imparted the absorption enhancing properties. Tetradecyl- $\beta$-D-maltoside (TDM) was shown to cause rapid and transient alteration of the 
rat nasal epithelia without causing any irreversible damage, as visualized by transmission electron microscopy. Administration of growth hormone with $0.125 \%$ TDM showed a marked increase in its absorption through nasal epithelium [46].

\section{Transdermal administration of hGH}

Zosano Pharma hGH (ZP-hGH) was formulated by coating liquid hGH formulation on a titanium microneedle array by dip coating followed by drying and evaluated for formulation stability and preclinical efficacy studies in female hairless guinea pigs. The formulation was stable for 6 months when stored at $40^{\circ} \mathrm{C}$ with no significant increase in \% aggregation as evaluated by size exclusion chromatography coupled HPLC (SEC-HPLC). 0.5 and $1 \mathrm{mg}$ doses on patches were compared to marketed Norditropin and both the formulations were shown to have similar efficacy and pharmacokinetics, thereby concluding that transdermal route could be exploited as an alternative to SC injections [47]. In vitro permeation studies using vertical Franz diffusion cell with dermatomed porcine ear skin were conducted to evaluate the effect of pore density created by laser abrasion on hGH permeability. Precise Laser Epidermal System (P.L.E.A.S.E.) was used to create different pore densities at varying fluences and it was shown that both the factors influenced the permeation of hGH through porcine skin [48].

\section{Micro and nano drug delivery systems}

Sustained release rhGH (SR-rhGH) hyaluronate microparticle based formulation was prepared by spray-drying and proved to be a successful sustained-release delivery system tested in cell proliferation assay and rat weight gain assay. The formulation revealed minimum dimerization (about 2\%) and absence of aggregates when spray dried at optimized parameters by the research group [49]. An injectable formulation of $100-200 \mathrm{~nm}$ size range nanogel of cinnamoyl alginate, cinnamoyl Pluronic F127 and cinnamoyl poly (ethylene glycol) with $3.33 \%(\mathrm{w} / \mathrm{w}$ ) hGH loading was injected in rats corresponding to $0.5 \mathrm{mg} \mathrm{hGH} / \mathrm{kg}$ body weight. It showed a higher AUC of hGH in blood for 7 days as compared to $0.05 \mathrm{mg} / \mathrm{kg}$ daily hGH. It was shown using fluorescence studies that the in vivo residence time of the nanogel was about $96 \mathrm{~h}$ [50]. Lyophilized coprecipitates of poly (vinyl pyruvate) (PVP) with poly (acrylic-acid cysteine) (PAA-cys) were micronized using jet milling to a size of about $3 \mu \mathrm{m}$ and harnessed for pulmonary delivery of insulin [51]. Although there is no proof of concept study of using this system for rhGH, it can be proposed to work for protein delivery. A diffusion controlled sustained release system of rhGH was achieved by encapsulating sugar glass-stabilized rhGH in electrosprun, bioresorbable poly (ether urea) nanofibers. The study showed positive efficacy results on $\mathrm{Nb}-2$ cell lines and burst release for at least 6 weeks [52]. Calcium carbonate particles are in the limelight for protein delivery strategies by their virtue to ionically interact with proteins. Ramalapa and group studied the fusion of protein of interest with human chitin binding domain (hcBD) that has inherent ability to bind to hyaluronic acid in order to enhance the drug loading on hyaluronic acid templated $\mathrm{CaCO}_{3}$ particles prepared with supercritical $\mathrm{CO}_{2}$. They validated a previous study that showed a significant (6-fold) enhancement of encapsulation efficiency and further demonstrated that introduction of Thrombin cleavage sites enhanced the protein release from $20 \%$ to about $90 \%$ [53].

\section{Challenges associated with the hGH therapy}

\section{Challenges associated with the approved formulations}

All the approved formulations are intended for once daily injection. Injectable formulations suffer from the key limitation of poor patient compliance, especially when the target group is pediatric. Moreover, the hGH therapy is a chronic hormone replacement therapy that may last for several years. hGH replacement is relatively rare, but an insulin injection website very effectively summarizes the challenges associated with once daily injections, that include injection site skin irritation, bruising, solution leakage from the injection device and at the site, clogging of the device sometimes, leading to added pain and so on. Also, daily injections are extremely challenging for the visually impaired population [54].

Nutropin was the only approved long acting formulation of $\mathrm{hGH}$. Although proven efficacious, this formulation showed a high patient to patient variability, as seen in the giant error bars in the graph in figure 4 [55]. This PLGA based formulation was withdrawn from the market after few years of exclusivity (1999-2004), the reason being the significant resources required for manufacturing and commercialization of the product' [56,57]. 


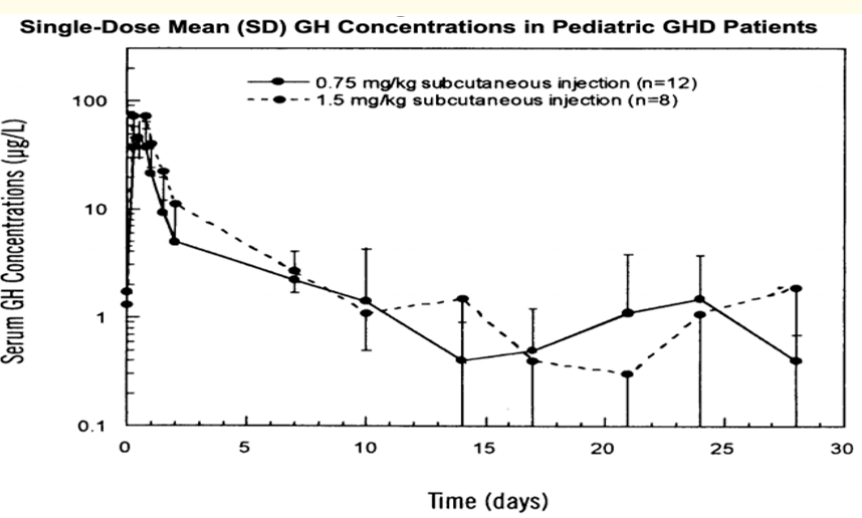

Figure 4: The graph of serum growth hormone profile for Nutropin Depot [55].

Difficulties associated with formulations in clinical trials

The unique chemistries

While derivatization of any protein into a stable variant is a brilliant approach to prolong its half-life intrinsically, every modification comes with its own share of disadvantages. While fusion protein approach provides half-life enhancement, it comes with several manufacturing difficulties such as stability, solubility and dosing challenges such as immunogenicity and reduction of potency [58]. The nominal half-life value of HSA in blood is 456 hours (19 days). However, there have been examples of withdrawal of these fusion proteins due to questionable safety profiles such as Albuferon and Egranli [58]. PEGylation is known to inhibit cellular uptake [59]. Besides, a review on alternative approaches to PEGylation cites several drawbacks associated with this technique, such as PEG bioaccumulation, hypersensitivity and antibody formation [60]. Lipidation of proteins for HSA binding is an excellent approach to enhance half-life without actual fusion to HSA. However, lipidated proteins may interact with proteins other than HSA [8], and although there is no written statement for this, this type of non-selective interaction may lead to variability between patients.

\section{Manufacturing difficulties}

Covalent linking of PEG or lipid chain to the protein of interest results usually in a heterogeneous mixture of conjugated products [61]. This type of non-specific conjugation with PEG or lipid chain leads to impaired protein function, difficulty in purification, char- acterization and evaluation of the protein [62]. Site-specific PEGylation typically requires enzymatic conjugation [63].

Problems with exploring alternative routes and nanoscale systems

While the idea of using micro and nanoscale formulations seems fascinating, the actual approval rates nanomedicine by FDA are significantly lower [64]. Challenges are associated with using micro and nano formulations at various levels. Large scale manufacturing, stability, intellectual property, quality control, government regulation and high manufacturing costs at an industry level coupled with complex biological behavior, biocompatibility and safety challenges and PK/PD challenges at a treatment level have been the hurdles in commercialization of nano-formulations [64]. Although the pulmonary and transdermal routes have given promises, they behold several challenges. Use of high concentrations of excipients such as surfactants or permeation enhancers may show good primary lab scale results, but in no way line up with the IIG limits set by FDA. For example, in the study outlining pulmonary delivery of hGH comparable to subcutaneous route discussed before, very high concentrations of Solutol HS15 have been used [43].

\section{Conclusion}

Over the past few decades, several efforts have been made to enhance the serum half-life of hGH. Among these, very few have made their way to the clinical trials, such as PEGylated hGH, fatty acid conjugated hGH with albumin binding abilities, hGH transiently bound to methoxy-PEG, fusion proteins of hGH with albumin, 28 residue C-terminal peptide of human chorionic gonadotropin, XTEN polypeptide. Understanding the unique chemistries or PK/ PD properties of each of these modifications is a prerequisite for further developing newer chemistries or delivery systems. Although alternative routes have been explored, such as nasal and transdermal, they are only at a proof of concept stage. A better commercial and manufacturing viability of these delivery systems, and clinical studies are still awaited. Hopefully, in the near future, newer human growth hormone delivery systems will emerge, leading to dosage forms with reduced dosing frequency and patient-topatient variability.

\section{Bibliography}

1. S R Rose. "Management options for pediatric growth hormone deficiency”. Expert Opinion on Orphan Drugs 7.2 (2019). 
2. B C Cunningham and J A Wells. "High-resolution epitope mapping of hGH-receptor interactions by alanine-scanning mutagenesis". Science (80-.) 244.4908 (1989): 1081-1085.

3. Y Cai., et al. "Developments in human growth hormone preparations: sustained-release, prolonged half-life, novel injection devices, and alternative delivery routes". International Journal of Nanomedicine 9 (2014): 3527.

4. M T Larsen., et al. "Albumin-based drug delivery: harnessing nature to cure disease". Molecular Therapy 4.1 (2016): 3.

5. U Fiedler., et al. "Recombinant binding proteins targeting her2 and serum albumin, and their uses". Google Patents, 07-Jun (2018).

6. J Cho., et al. "Generation of therapeutic protein variants with the human serum albumin binding capacity via site-specific fatty acid conjugation". Scientific Report 7.1 (2017): 18041.

7. E Adabi., et al. "Evaluation of an albumin-binding domain protein fused to recombinant human IL-2 and its effects on the bioactivity and serum half-life of the cytokine". Iranian Biomedical Journal 21.2 (2017): 77.

8. EM Bech., et al. "Chemical Strategies for Half-Life Extension of Biopharmaceuticals: Lipidation and Its Alternatives". ACS Publications (2018).

9. P Thygesen., et al. "Preclinical characterisation of NNC01950092, a long-acting GH". in 15th European Congress of Endocrinology 32 (2012).

10. M H Rasmussen., et al. "A reversible albumin-binding growth hormone derivative is well tolerated and possesses a potential once-weekly treatment profile". The Journal of Clinical Endocrinology and Metabolism 99.10 (2014): E1819-E1829.

11. MH Rasmussen., et al. "Reversible albumin-binding GH possesses a potential once-weekly treatment profile in adult growth hormone deficiency". The Journal of Clinical Endocrinology and Metabolism 101.3 (20186): 988-998.

12. MH Rasmussen., et al. "Sc Injections of a Reversible AlbuminBinding GH Derivative (NNC0195-0092) in Adult Subjects with GH Deficiency is Well Tolerated". in ESPE 2014 (2014): 82.

13. N Zuckerman-Levin., et al. "A Novel Reversible Albumin-Binding GH Derivative Possesses a Promising Once-Weekly Treatment Profile in Children with GH Deficiency". in 54th Annual ESPE (2015): 84.
14. C A R T-Cells. "New phase 2 data for somapacitan demonstrate its potential as an efficacious once-weekly treatment for childhood growth hormone deficiency".

15. TOXNET. “Substance Name: Somapacitan USAN:INN” (2019).

16. R A Ningrum., et al. "Overproduction, purification and characterization of human interferon alpha2a-human serum albumin fusion protein produced in methilotropic yeast Pichia pastoris". in Journal of Physics: Conference Series 835.1 (2017): 12013.

17. B Guan., et al. "Effects of co-overexpression of secretion helper factors on the secretion of a HSA fusion protein (IL2-HSA) in pichia pastoris". Yeast 33.11 (2016): 587-600.

18. S Xia., et al. "Construction and expression of releasable glucagon-like peptide- 1 and human serum albumin fusion proteins and preliminary evaluation of their pharmacodynamics and pharmacokinetics". Military Medical Research 8 (2015): 587592.

19. Cohen-Barak., et al. "Safety, pharmacokinetic and pharmacodynamic properties of TV-1106, a long-acting GH treatment for GH deficiency". European Journal of Endocrinology 173.5 (2015): 541-551.

20. N Ashkenazi., et al. "Safety and PK/PD correlation of TV-1106, a recombinant fused human albumin-growth hormone, following repeat dose administration to monkeys". Growth Hormone and IGF Research 30 (2016): 16-21.

21. Cohen-Barak., et al. "Assessment of the Pharmacokinetics, Pharmacodynamics, and Safety of Single Doses of TV-1106, a Long-Acting Growth Hormone, in Healthy Japanese and Caucasian Subjects". Clinical Pharmacology in Drug Development 6.4 (2017): 331-342.

22. Cohen-Barak., et al. "The Pharmacokinetics and Pharmacodynamics of TV-1106, a Once Weekly GH Supplement: Results from a Phase 2 Study of TV-1106 in Adults with GH Deficiency". in 54th Annual ESPE 84 (2015).

23. L Hou., et al. "Comparative pharmacokinetics and pharmacodynamics of a PEGylated recombinant human growth hormone and daily recombinant human growth hormone in growth hormone-deficient children". Drug Design, Development and Therapy 10 (2016): 13. 
24. Y Guan., et al. "A long-acting pegylated recombinant human growth hormone (Jintrolong®) in healthy adult subjects: Two single-dose trials evaluating safety, tolerability and pharmacokinetics". Journal of Clinical Pharmacy and Therapeutics 43.5 (2018): 640-646.

25. M Karbasian., et al. "Design, development and evaluation of PEGylated rhGH with preserving its bioactivity at highest level after modification". International Journal of Pharmaceutics 557 (2019): 9-17.

26. X Luo., et al. "A long-acting pegylated recombinant human growth hormone (Jintrolong®) in healthy adult subjects: Two single-dose trials evaluating safety, tolerability and pharmacokinetics". European Journal of Endocrinology 177.2 (2017): 195-205.

27. Hershkovitz., et al. "In vitro and in vivo characterization of MOD-4023, a long-acting carboxy-terminal peptide (CTP)modified human growth hormone". Molecular Pharmaceutics 13.2 (2016): 631-639.

28. WG Kramer., et al. "Pharmacokinetics, Pharmacodynamics, and Safety of a Long-Acting Human Growth Hormone (MOD-4023) in Healthy Japanese and Caucasian Adults". Clinical Pharmacology in Drug Development 7.5 (2018): 554-563.

29. N Zelinska., et al. "Long-Acting C-Terminal Peptide-Modified hGH (MOD-4023): Results of a Safety and Dose-Finding Study in GHD Children". The Journal of Clinical Endocrinology and Metabolism 102.5 (2017): 1578-1587.

30. C J Strasburger., et al. "MOD-4023, a long-acting carboxy-terminal peptide-modified human growth hormone: results of a Phase 2 study in growth hormone-deficient adults". European Journal of Endocrinology 176.3 (2017): 283-294.

31. K Sprogøe., et al. "The rationale and design of TransCon Growth Hormone for the treatment of growth hormone deficiency". Endocrine Connection 6.8 (2017): R171-R181.

32. P Chatelain., et al. "A randomized phase 2 study of long-acting TransCon GH vs daily GH in childhood GH deficiency". The Journal of Clinical Endocrinology and Metabolism 102.5 (2017): 1673-1682.

33. D Gilfoyle., et al. "A first-in-man phase 1 trial for long-acting TransCon Growth Hormone". Growth Hormone and IGF Research 39 (2018): 34-39.

34. C Höybye., et al. "A phase 2 trial of long-acting TransCon growth hormone in adult GH deficiency". Endocrine Connection 6.3 (2017): 129-138.
35. V Schellenberger., et al. "A recombinant polypeptide extends the in vivo half-life of peptides and proteins in a tunable manner". Nature Biotechnology 27.12 (2009): 1186.

36. J L Cleland., et al. "A novel long-acting human growth hormone fusion protein (vrs-317): enhanced in vivo potency and halflife". Journal of Pharmaceutical Sciences 101.8 (2012): 27442754.

37. W V Moore., et al. "A randomized safety and efficacy study of somavaratan (VRS-317), a long-acting $\mathrm{rhGH}$, in pediatric growth hormone deficiency". The Journal of Clinical Endocrinology and Metabolism 101.3 (2016): 1091-1097.

38. BS Miller., et al. "3-year safety and efficacy Update of the VERTICAL and VISTA trials of somavaratan (VRS-317), a long-acting rhGH, in children with Growth Hormone Deficiency (GHD)". in 19th European Congress of Endocrinology 49 (2017).

39. J S Patil and S Sarasija. "Pulmonary drug delivery strategies: A concise, systematic review". Lung India: Official Organ of Indian Chest Society's 29.1 (2012): 44.

40. YZ Li., et al. "Inhalable microparticles as carriers for pulmonary delivery of thymopentin-loaded solid lipid nanoparticles". Pharmaceutical Research 27.9 (2010): 1977-1986.

41. F Andrade., et al. "Nanocarriers for pulmonary administration of peptides and therapeutic proteins". Nanomedicine 6.1 (2011): 123-141.

42. J S Patton., et al. "Methods and compositions for pulmonary delivery of insulin". Google Patents 21-Apr- (2009).

43. L Illum., et al. "CriticalSorb" ${ }^{\mathrm{TM}}$ : A novel efficient nasal delivery system for human growth hormone based on Solutol HS15". Journal of Control Release 162.1 (2012): 194-200.

44. D Kilian., et al. "Vesicular carriers for skin drug delivery: the Pheroid ${ }^{\mathrm{TM}}$ technology". Current Pharmaceutical Design 21.20 (2015): 2758-2770.

45. D Steyn., et al. "Nasal delivery of recombinant human growth hormone: in vivo evaluation with Pheroid ${ }^{\mathrm{TM}}$ technology and Ntrimethyl chitosan chloride". Journal of Pharmacy and Pharmaceutical Sciences 13.2 (2010): 263-273.

46. JJ Arnold., et al. "Reestablishment of the nasal permeability barrier to several peptides following exposure to the absorption enhancer tetradecyl- $\beta$-D-maltoside". Journal of Pharmaceutical Sciences (2010). 
47. M Ameri., et al. "Human growth hormone delivery with a microneedle transdermal system: preclinical formulation, stability, delivery and PK of therapeutically relevant doses". Pharmaceutics 6.2 (2014): 220-234.

48. Y Song., et al. "Transdermal delivery of human growth hormone via laser-generated micropores". Drug Delivery and Translational Research 8.2 (2018): 450-460.

49. S J Kim and C W Kim. "Development and characterization of sodium hyaluronate microparticle-based sustained release formulation of recombinant human growth hormone prepared by Spray-Drying". Journal of Pharmaceutical Sciences 105.2 (2016): 613-622.

50. D Y Yoon and JC Kim. "In vivo residence duration of human growth hormone loaded in nanogels comprising cinnamoyl alginate, cinnamoyl Pluronic F127 and cinnamoyl poly (ethylene glycol)". International Journal of Pharmaceutics 509.1-2 (2016): 229-236.

51. B Deutel., et al. "In vitro characterization of insulin containing thiomeric microparticles as nasal drug delivery system". European Journal of Pharmaceutical Sciences 81 (2016): 157-161.

52. Y Gao., et al. "Sustained release of recombinant human growth hormone from bioresorbable poly (ester urea) nanofibers". ACS Macro Letter 6.8 (2017): 875-880.

53. B Ramalapa., et al. "Protein-polysaccharide complexes for enhanced protein delivery in hyaluronic acid templated calcium carbonate microparticles". Journal of Materials Chemistry B 5.35 (2017): 7360-7368.

54. BD. "Common Injection challenges".

55. FDA. "Nutropin Depot somatropin (rDNA origin) for injectable suspension" (2019).

56. ICIS news. "US firms announce discontinuance of 'Nutropin Depot'” (2004).

57. Genentech. "Genentech and Alkermes Announce Decision to Discontinue Commercialization of Nutropin Depot" (2004).

58. W R Strohl. "Fusion proteins for half-life extension of biologics as a strategy to make biobetters". BioDrugs 29.4 (2015): 215239.

59. H Hatakeyama., et al. "The polyethyleneglycol dilemma: advantage and disadvantage of PEGylation of liposomes for systemic genes and nucleic acids delivery to tumors". Biological and Pharmaceutical Bulletin 36.6 (2013): 892-899.
60. S B van Witteloostuijn., et al. "Half-life extension of biopharmaceuticals using chemical methods: alternatives to PEGylation". ChemMedChem 11.22 (2016): 2474-2495.

61. P Hazra., et al. "Development of a process to manufacture PEGylated orally bioavailable insulin". Biotechnology Progress 26.6 (2010): 1695-1704.

62. H Shi., et al. "Site-specific PEGylation of Human Growth Hormone by Mutated Sortase A". Chemical Research in Chinese Universities 34.3 (2018): 428-433.

63. A Grigoletto., et al. "Chemical and Enzymatic Site Specific PEGylation of hGH: The Stability and in vivo Activity of PEG-NTerminal-hGH and PEG-Gln141-hGH Conjugates". Macromolecular Bioscience 16.1 (2016): 50-56.

64. D Bobo., et al. "Nanoparticle-based medicines: a review of FDA-approved materials and clinical trials to date". Pharmaceutical Research 33.10 (2016): 2373-2387.

65. FDA. "Humatrope ${ }^{\circledR}$ (Somatropin, rDNA Origin, for Injection)”.

66. FDA. "GENOTROPIN:somatropin rDNA origin".

67. FDA. "Saizen®Somatropin (rDNA origin) for injection.,For subcutaneous or intramuscular injection".

68. FDA. "Norditropin $®$ (somatropin) injection, for subcutaneous use" (2019).

69. FDA. "TEV-TROPIN®somatropin (rDNA origin) for injection" (2019).

70. FDA. "OMNITROPETM somatropin (rDNA origin) injection., for subcutaneous use" (2019).

Volume 4 Issue 10 October 2021 (C) All rights are reserved by Srushti Sodha. 